\title{
Vitrification of in vitro matured oocytes collected from antral follicles at the time of ovarian tissue cryopreservation
}

\author{
Giovanna Fasano ${ }^{1,2^{*}}$, Federica Moffa ${ }^{2}$, Julie Dechène ${ }^{1}, Y_{\text {von Englert }}^{1,2}$ and Isabelle Demeestere ${ }^{1,2}$
}

\begin{abstract}
Background: In the past few years, cryopreservation of ovarian tissue has become an established procedure proposed in many centers around the world and transplantation has successfully resulted in full-term pregnancies and deliveries in human. This prospective study aims to evaluate the feasibility of vitrifying in vitro matured oocytes (IVM) isolated at the time of ovarian tissue cryopreservation to improve the efficiency of fertility preservation programs.

Methods: Oocyte-cumulus complexes were retrieved from freshly collected ovarian cortex by aspirating antral follicular fluid, and were matured in vitro for 24-48 h prior to vitrification. Oocytes were matured in an IVM commercial medium (Copper Surgical, USA) supplemented with $75 \mathrm{mlU} / \mathrm{ml} \mathrm{FSH}$ and $75 \mathrm{mlU} / \mathrm{ml} \mathrm{LH}$ and vitrified using a commercial vitrification kit (Irvine Scientific, California) in high security vitrification straws (CryoBioSystem, France). Oocyte collection and IVM rates were evaluated according to the age, the cycle period and the amount of tissue collected.

Results: Immature oocyte retrieval from ovarian tissue was carried out in 57 patients between 8 and 35 years of age, undergoing ovarian tissue cryopreservation. A total of 266 oocytes were isolated, 28 of them were degenerated, 200 were at germinal vesicle stage (GV), 35 were in metaphase I (MI) and 3 displayed a visible polar body (MII). The number of oocytes collected was positively correlated with the amount of tissue cryopreserved ( $p$ $<0.001)$ and negatively correlated with the age of the patients $(p=0.005)$. Oocytes were obtained regardless of menstrual cycle period or contraception. A total maturation rate of $31 \%$ was achieved, leading to the vitrification of at least one mature oocyte for half of the cohort.
\end{abstract}

Conclusions: The study showed that a significant number of immature oocytes can be collected from excised ovarian tissue whatever the menstrual cycle phases and the age of the patients, even for prepubertal girls.

\section{Background}

Advances in cancer therapy have improved the longterm survival of patients suffering from malignancies. Thus, the number of young adults wishing to become parents following cancer treatment has significantly increased. However, cancer treatment often involves adverse side effects, including loss of gonadal function and sterility $[1,2]$. Chemotherapy using high doses of alkylating agents and radiotherapy by ionizing radiation reduces the primordial follicle reserve, which may

\footnotetext{
* Correspondence: Giovanna.Fasano@erasme.ulb.ac.be

'Research Laboratory on Human Reproduction, Faculty of Medicine, Campus Erasme, Université Libre de Bruxelles, 1070 Brussels, Belgium

Full list of author information is available at the end of the article
}

trigger premature ovarian failure (POF). This represents a major concern for young patients hoping to have children. In this context, all options for maintaining or restoring fertility must be considered [3,4]. Oocytes and embryos can be vitrified after ovarian stimulation or during a natural cycle, but this strategy is not recommended to all patients [5-7]. Furthermore, the number of oocytes or embryos vitrified is often not sufficient for more than one or two transfer attempts.

In the past few years, cryopreservation of ovarian tissue has become an established procedure proposed in many centers around the world in order to store a large amount of primordial follicles prior to gonadotoxic treatment [8-10]. Cryopreservation and transplantation

\section{Biomed Central}


of ovarian tissue have successfully resulted in full-term pregnancies and deliveries in humans [11]. One of the major issues regarding ovarian tissue transplantation is the risk of transmission of cancer cells that may have infiltrated the ovarian tissue before the cryopreservation procedure. In these cases, alternatives include in vitro growth of primordial follicles but unfortunately ovarian tissue culture system is not yet available for human application $[12,13]$. Furthermore, ovarian tissue cryopreservation preserves the primordial and primary follicles, but not the immature oocytes within the antral follicles that do not survive the procedure. These oocytes could however be recovered and subjected to in vitro maturation (IVM) [14]. As reported by many authors, healthy infants were born following IVM $[15,16]$. Vitrification is now a widely applied and highly successful approach for cryopreservation in reproductive biology, including for the storage of human oocytes [17-19]. Recently, studies reported almost $100 \%$ morphological survival rate after vitrification of in vivo aspirated mature oocytes. The authors also reported in vitro embryo development, implantation and pregnancy rates comparable to those achieved with fresh oocytes [20-22].

The present study assessed the efficiency of IVM and vitrification procedures of the immature oocytes in excised ovarian tissue according to the age of the patients and their menstrual cycles.

\section{Methods}

The procedure was approved by the local ethical committee. It was explained to patients and informed consent was obtained.

\section{Patients}

From November 2008 to December 2010, 57 patients between 8 and 35 years of age (mean age 26), referred to Erasme Hospital for ovarian tissue cryopreservation as part of a fertility preservation program, underwent a combined oocyte vitrification procedure after counseling. Seven patients underwent oophorectomy, while the others had ovarian cortex biopsies. The indications for ovarian tissue cryopreservation were breast cancers ( $\mathrm{n}=$ $26)$, hematological diseases $(n=20)$, gynecological diseases $(n=7)$, solid malignancies $(n=2)$ and autoimmune diseases $(n=2)$. The inclusion criteria for the cryopreservation of ovarian tissue were previously described [8]. Patients treated with chemotherapy before the ovarian tissue cryopreservation procedure were excluded from this study [23].

\section{Oocyte collection and in vitro maturation}

The surgical collection and freezing procedures for the ovarian tissue were described elsewhere [8]. Large biopsies of the ovarian cortex (approximately total of half ovary) were removed by laparoscopy except for patients treated with high-dose alkylating agents and autologous stem-cell transplantation, who underwent a unilateral oophorectomy considering their high risk of premature ovarian failure. Oophorectomy was also required in some ovarian diseases, but only a part of the cortex was designated for cryopreservation in these patients. The ovarian cortex was transported to the IVF laboratory in Leibovitz L-15 medium (Life Technologies, Merelbeke, Belgium) at $4^{\circ} \mathrm{C}$ within the hour. At arrival, oocytecumulus complexes (OCCs) were recovered by aspirating all visible antral follicles using 18-gauge syringe needles. The aspirated follicular fluid was poured directly into a Petri dish and examined for OCCs under a stereomicroscope. The ovarian specimens were transferred into a new dish containing the same medium and carefully dissected in order to obtain small slices of ovarian cortex (0.5-1 cm diameter, 1-2 mm thickness). After dissection of the ovarian tissue, the discarded material was filtered through a cell strainer (Falcon, Cell Strainer 352350, $70 \mu \mathrm{m}$ Nylon) in a Petri dish (Falcon, Petri dishes $3004,60 \times 15 \mathrm{~mm}$ ) containing 3-5 $\mathrm{ml}$ of IVM Washing Medium (Sage, IVM Kit media) at $37^{\circ} \mathrm{C}$ on a warm stage or plate to prevent the OCCs from drying in the strainer. After filtering, the collected material was rinsed with pre-warmed IVM Washing Medium and transferred into a Petri dish to search a second time for OCCs under a stereomicroscope. All retrieved OCCs were scored and classified according to the oocyte nuclear stage as germinal vesicle (GV), germinal vesicle breakdown (metaphase I-MI) or metaphase II when a first polar body is visible in the perivitelline space (MII). OCCs with unvisualized oocyte nuclear status due to the compact cumulus cells surrounded it were considered as GV. OCCs were washed at least three times in pre-warmed IVM Washing Medium and transferred into an Organ Tissue Culture Dish (Nunc, 176742, 4 wells dishes) containing $0.5 \mathrm{ml}$ IVM Maturation Medium (Sage, IVM Kit media) supplemented with $75 \mathrm{mIU} /$ $\mathrm{ml} \mathrm{FSH}$ and $75 \mathrm{mIU} / \mathrm{ml} \mathrm{LH}$ and incubated at $37^{\circ} \mathrm{C}$ in a $5 \% \mathrm{CO}_{2}$ humidified atmosphere. The IVM Maturation Medium was prepared for equilibration at least two hours before the immature oocyte retrieval. The immature OCCs were cultured in the IVM Maturation Medium for 24 to 48 hours.

\section{Vitrification}

Twenty-four hours after IVM, all the OCCs were denuded using a 130 micron finely drawn pipette following one minute of exposure to $80 \mathrm{IU} / \mathrm{ml}$ hyaluronidase solution (Sigma Aldrich SrL, UK.). The mature oocytes (MII) were then subjected to vitrification following a standard protocol (Irvine, Vitrification Kit media) using aseptic devices (CryoBiosystem, VHS Kit). The 
remaining immature oocytes (GV and $\mathrm{MI}$ ) were kept in IVM Maturation Medium for an additional 24 hours.

Forty-eight hours after IVM, the remaining oocytes that reached MII were vitrified.

\section{Statistical analysis}

Statistical analyses were performed using the Chisquared, t-Test and Non parametric Mann-Whitney Test as appropriate. Linear correlations between two variables were analyzed by calculation of the $r$-values (Pearson's moment-correlation coefficient); the significance (two-tailed probability values) of $\mathrm{r}$ coefficients were calculated on the basis of the correlation values. Values of $p<0.05$ indicated statistical significance.

\section{Results}

From the cohort of 57 patients, 19\% were using contraception treatment (mean age 23.1, range 17-33), 33\% were in the follicular phase of a spontaneous menstrual cycle (mean age 26.3, range 14-35), 28\% were in the luteal phase (mean age 27.9, range $22-34$ ), $7 \%$ were prepubertal (mean age 9.2, range $8-13$ ), 9\% were in postpartum amenorrhea (mean age 31, range 23-35) and for 2 patients, information was unavailable (Table 1 ). A total of 266 oocytes were retrieved, 28 of them were degenerated $(10.5 \%)$. In the 238 healthy oocytes, 200 were at germinal vesicle stage (GV), 35 were in metaphase I (MI) and 3 displayed a visible polar body (MII).

In $15 / 57$ patients, no oocytes were found (26.3\%). The number of oocytes collected was positively correlated with the amount of tissue cryopreserved $(p<0.001)$ and negatively correlated with the age of the patients ( $p=$ $0.005)$. As shown in Table 1 immature oocytes were retrieved regardless of the menstrual cycle phases. The mean number of oocytes retrieved was however higher in prepubertal compared to post-pubertal patients (Table 1). For post-pubertal patients, no difference in the number of oocyte collected was observed between patients less or over 30 year-old (Table 2).

The total IVM rate was 31\% (20\% after $24 \mathrm{~h}$ IVM and $11 \%$ after $48 \mathrm{~h}$ IVM). For patients with natural cycles, the IVM rate was similar whatever the phase of the menstrual cycle. No significant difference was observed in the maturation rate between patients using contraception or those in a natural cycle as well as between pre- and post-pubertal patients. For 3 patients, in vitro matured oocytes (4, 1 and 5 respectively) were fertilized by ICSI and the embryos obtained (1, 1 and 3 respectively) were vitrified.

In more than half of the patients (54\%), at least one mature oocyte was vitrified after 24 or 48 hours. In $3 / 4$ prepubertal patients, MII were vitrified, suggesting that the procedure is suitable and more efficient for prepubertal patients where antral follicles are present.

\section{Discussion}

The cryopreservation of ovarian tissue allows the preservation of a large number of primary follicles before gonadotoxic treatment. However, growing immature oocytes from antral follicles are lost during the procedure. Vitrification of in vitro matured oocytes collected after punction of these antral follicles in the excised ovarian tissue before cryopreservation has been proposed as an additional technique to preserve fertility. This procedure may increase fertility restoration potential and may also be an important alternative whereby neoplasic cells can potentially infiltrate ovarian tissue, leading to a risk of disease recurrence after transplantation, as in some hematological diseases or in advanced breast cancer [24,25].

This study shows that isolated immature oocytes from antral follicles can be retrieved from the ovarian tissue biopsy, consequently in vitro matured and vitrified during any phase of the menstrual cycle and whether or

Table 1 Outcome of immature oocyte retrieved from ovarian cortex according to the menstrual cycle characteristic

\begin{tabular}{|c|c|c|c|c|c|c|c|c|c|c|}
\hline \multirow[t]{2}{*}{$\begin{array}{l}\text { Characteristic of the } \\
\text { patient's menstrual cycle }\end{array}$} & \multirow[t]{2}{*}{$\begin{array}{l}\text { Patients } \\
\mathrm{n}\end{array}$} & \multirow{2}{*}{$\begin{array}{c}\text { Mean } \\
\text { age } \pm \\
\text { SEM }\end{array}$} & \multirow[t]{2}{*}{$\begin{array}{l}\text { Mean fragments of } \\
\text { ovarian tissue (range) }\end{array}$} & \multirow{2}{*}{$\begin{array}{l}\text { Oocytes } \\
\text { retrieved } \\
\text { n (range) }\end{array}$} & \multirow{2}{*}{$\begin{array}{c}\text { Mean } \\
\text { oocytes } \\
\text { retrieved } \\
\text { /fragment }\end{array}$} & \multirow{2}{*}{$\begin{array}{c}\text { Mean } \\
\text { oocytes } \\
\text { retrieved } \\
\text { /patients }\end{array}$} & \multicolumn{3}{|c|}{$\begin{array}{c}\text { Stage at } \\
\text { collection (\%) }\end{array}$} & \multirow[t]{2}{*}{$\begin{array}{l}\text { IVM } \\
\text { rate }\end{array}$} \\
\hline & & & & & & & GV & MI & MII & \\
\hline$O C$ & 11 & $23.1 \pm 1.3$ & $20.1(10-29)$ & $38(0-9)$ & $0.17 \pm 0.07^{\mathrm{a}}$ & $3.4 \pm 1.06^{\mathrm{a}}$ & $71 \%$ & $29 \%$ & $0 \%$ & $42.1 \%$ \\
\hline Natural cycle FP & 19 & $26.3 \pm 1.5$ & $21.6(7-32)$ & $69(0-15)$ & $0.17 \pm 0.06^{\mathrm{a}}$ & $3.6 \pm 1.09^{\mathrm{a}}$ & $80 \%$ & $19 \%$ & $1 \%$ & $27.9 \%$ \\
\hline Natural cycle LP & 16 & $27.9 \pm 1.1$ & $18.1(12-26)$ & $44(0-13)$ & $0.15 \pm 0.05^{\mathrm{a}}$ & $2.8 \pm 0.83^{\mathrm{a}}$ & $84 \%$ & $14 \%$ & $2 \%$ & $39.5 \%$ \\
\hline Post-partum & 5 & $31 \pm 2.2$ & $26.3(16-36)$ & $33(1-12)$ & $0.23 \pm 0.12^{\mathrm{a}}$ & $6.6 \pm 1.86$ & $91 \%$ & $6 \%$ & $3 \%$ & $28.1 \%$ \\
\hline Unknown & 2 & $29.5 \pm 0.5$ & $20-32$ & $8(0-8)$ & $0.15 \pm 0.26$ & $4 \pm 4$ & $100 \%$ & $0 \%$ & $0 \%$ & $12.5 \%$ \\
\hline Prepubertal & 4 & $9.2 \pm 1.4$ & $31.7(17-40)$ & $46(2-22)$ & $0.36 \pm 0.28^{b}$ & $11.5 \pm 4.27^{\mathrm{b}}$ & $93 \%$ & $7 \%$ & $0 \%$ & $23.9 \%$ \\
\hline Total & 57 & $26 \pm 0.9$ & $21.8(7-40)$ & $238(0-22)$ & 0.19 & 4 & $84 \%$ & $14.7 \%$ & $1.3 \%$ & $31 \%$ \\
\hline
\end{tabular}

$\mathrm{GV}=$ germinal vesicle; $\mathrm{MI}=$ metaphase $\mathrm{I} ; \mathrm{MII}=$ metaphase $\mathrm{II} ; \mathrm{OC}=$ oral contraception; $\mathrm{FP}=$ follicular phase; $\mathrm{LP}=$ luteal phase; IVM = in vitro maturation; $\mathrm{n}=$ number;

$\mathrm{a}$ vs $\mathrm{b}$ within the same column, $p<0.05$ 
Table 2 Outcome of immature oocyte retrieved from ovarian tissue of post-pubertal patients according to the age

\begin{tabular}{|c|c|c|c|c|c|c|c|c|c|c|}
\hline \multirow[t]{2}{*}{ Age } & \multirow[t]{2}{*}{$\begin{array}{l}\text { Patients } \\
\mathrm{n}\end{array}$} & \multirow[t]{2}{*}{$\begin{array}{l}\text { Mean age } \\
\pm \text { SEM }\end{array}$} & \multirow[t]{2}{*}{$\begin{array}{l}\text { Mean fragments of ovarian } \\
\text { tissue (range) }\end{array}$} & \multirow{2}{*}{$\begin{array}{l}\text { Oocytes } \\
\text { retrieved } \\
\mathrm{n} \text { (range) }\end{array}$} & \multirow{2}{*}{$\begin{array}{l}\text { Mean oocytes } \\
\text { retrieved } \\
\text { /fragment }\end{array}$} & \multirow{2}{*}{$\begin{array}{l}\text { Mean oocytes } \\
\text { retrieved } \\
\text { /patients }\end{array}$} & \multicolumn{3}{|c|}{$\begin{array}{c}\text { Stage at } \\
\text { collection (\%) }\end{array}$} & \multirow[t]{2}{*}{$\begin{array}{l}\text { IVM } \\
\text { rate }\end{array}$} \\
\hline & & & & & & & GV & MI & MII & \\
\hline $\begin{array}{l}<30 \\
\text { years }\end{array}$ & 30 & $23.6 \pm 0.71$ & $21(7-32)$ & $99(0-10)$ & $0.16 \pm 0.02$ & $3.3 \pm 0.53$ & $83.8 \%$ & $15.1 \%$ & $1 \%$ & $31.3 \%$ \\
\hline $\begin{array}{l}\geq 30 \\
\text { years }\end{array}$ & 23 & $32 \pm 0.40$ & $20.9(11-36)$ & $93(0-15)$ & $0.18 \pm 0.04$ & $4 \pm 1.04$ & $79.6 \%$ & $18.3 \%$ & $2.1 \%$ & $30.3 \%$ \\
\hline
\end{tabular}

$\mathrm{GV}=$ germinal vesicle; $\mathrm{MI}=$ metaphase $\mathrm{I} ; \mathrm{MII}=$ metaphase II; $\mathrm{OC}=$ oral contraception; $\mathrm{FP}=$ follicular phase; $\mathrm{LP}=$ luteal phase; IVM = in vitro maturation; $\mathrm{n}=$ number

not the patient is using oral contraception. The number of oocytes collected is correlated with the number of cryopreserved fragments and the age of the patients. However, the IVM rate is similar whatever the phase of the menstrual cycles or the age of patient. These results suggest that the procedure can be proposed to any patient undergoing ovarian tissue cryopreservation, with the exception of those who have already begun chemotherapy.

The procedure described above, allows the vitrification of matured oocytes in approximately half of the patients although the total IVM rate was lower than the one previously described using oocytes directly retrieved in vivo. In a recent study, a mean oocyte maturation rate of around $70 \%$ was achieved following direct oocyte retrieval after hCG injection during a natural cycle [26]. The recent success of in vitro oocyte maturation strategies has been attributed to the improvement of the culture media composition [27-29]. In immature oocytes retrieved from ovarian tissue, the delay in relation to transport and oocyte collection is a major issue and may decrease the efficiency of IVM. Revel et al. [30] first described oocyte collection during the cryopreservation of ovarian tissue in 9 patients, amongst whom 3 attempted IVM. In these patients, 5 of 8 MI oocytes were matured in vitro. Other studies including small number of patients or case reports have been described, confirming the feasibility of the procedure [31-33]. In our cohort, the IVM rate was highly variable from one patient to other ranging from 0 to $100 \%$, with an average of $31 \%$. This result is consistent with the only previous study using a large cohort of 19 patients under 20 years of age, showing that $34 \%$ of immature oocytes collected from ovarian tissue before cryopreservation are competent to resume meiosis in vitro [34].

Healthy infants have been born following IVM [35-37], and oocyte cryopreservation by vitrification seems a promising technique that appears to be more effective than the conventional slow-freezing method for mature oocytes vitrified shortly after collection [38-40]. In this context, vitrification results in high survival rates of $89-100 \%$ and many successful live births worldwide
[41-43]. Given these recent successes, although the efficiency of this combined procedure has to be determined by testing the potential for the implantation of embryos derived from these in vitro matured and vitrified oocytes, it is reasonable to suggest this innovative and non-invasive alternative, under institutional review board supervision. Furthermore, if a male partner is present, the in vitro matured oocytes may be fertilized using the in vitro fertilization (IVF) technique, and the resulting embryos may be cryopreserved. For 3 patients, in vitro matured oocytes were fertilized and the embryos obtained were vitrified. Theses cases are reassuring regarding the oocyte quality as it suggests that these oocytes are competent to be fertilized.

\section{Conclusion}

This study shows that the combination of ovarian tissue cryopreservation and immature oocyte retrieval is feasible whatever the phase of menstrual cycle, the use of oral contraception or the age of the patient. Approximately half of these patients should benefit from this combined procedure, and improvement of the IVM rate may better increase the efficiency of the procedure in the future.

\section{Acknowledgements}

The study was supported by an unconditional grant from the Fonds National Recherche Scientifique (FNRS) of Belgium, and an unconditional grant from Ferring Pharmaceuticals.

\section{Author details}

${ }^{1}$ Research Laboratory on Human Reproduction, Faculty of Medicine, Campus Erasme, Université Libre de Bruxelles, 1070 Brussels, Belgium. ${ }^{2}$ Fertility Clinic, Department of Obstetrics and Gynaecology, Erasme Hospital, Université Libre de Bruxelles, 1070 Brussels, Belgium.

\section{Authors' contributions}

GF performed the study and wrote the manuscript. FM enrolled the patients, participated in critical discussion and revised the manuscript. JD performed the technical assistance for laboratory procedure and participated in the data collection and analysis. YE is the director of the project, participated in the study design and in critical discussion and revised the manuscript. ID is responsible for the fertility preservation project, participated in the study design and in critical discussion and revised the manuscript. All authors read and approved the final manuscript.

\section{Competing interests}

The authors declare that they have no competing interests. 
Received: 5 September 2011 Accepted: 23 November 2011

Published: 23 November 2011

\section{References}

1. Bath LE, Anderson RA, Critchley HO, Kelnar CJ, Wallace WH: Hypotalamicpitutary-ovarian dysfunction after prepubertal chemotherapy and cranial irradiation for acute leukemia. Hum Reprod 2001, 16:1838-1844.

2. Salooja N, Szydlo RM, Socie G, Rio B, Chatterjee R, Ljungman P, Van Lint MT, Powles R, Jackson G, Hinterberger-Fischer M, Kolb HJ, Apperley JF: Pregnancies outcome after peripheral blood or bone transplantation: a retrospective survey. Lancet 2001, 354:271-276.

3. Lobo RA: Potential options for preservation of fertility in women. $N$ Engl J Med 2005, 353:64-67.

4. Woodruff TK: Preserving fertility during cancer treatment. Nat Med 2009, 15:1124-1125

5. Huang JY, Tulandi T, Holzer H, Tan SL, Chian RC: Combining ovarian tissue cryobanking whit retrieval of immature oocytes followed by in vitro maturation and vitrification: an additional strategy of fertility preservation. Fertil Steril 2008, 89:567-572.

6. Noyes N, Labella PA, Grifo J, Knopman JM: Oocyte cryopreservation: a feasible fertility preservation option for reproductive age cancer survivors. J Assist Reprod Genet 2010, 27:495-499.

7. Otkay K, Buyuk E, Davis O, Yermakova I, Veeck L, Rosenwaks Z: Fertility preservation in breast cancer patients: IVF and embryo cryopreservation after ovarian stimulation with tamoxifen. Hum Reprod 2003, 18:90-95.

8. Demeestere I, Simon P, Englert $Y$, Delbaere A: Preliminary experience of ovarian tissue cryopreservation procedure: alternatives, perspectives and feasibility. Reprod Biomed Online 2003, 7:572-579.

9. Donnez J, Martinez-Madrid B, Jadoul P, Van Langendonckt A, Demylle D, Dolmans MM: Ovarian tissue cryopreservation and transplantation: a review. Hum Reprod Update 2006, 12:519-535.

10. Moffa F, Biacchiardi CP, Fagioli F, Biasin E, Revelli A, Massobrio M, Madon E: Ovarian tissue cryostorage and grafting: an option to preserve fertility in paediatric patients with malignancies. Pediatr Hematol Oncol 2007, 24:29-44.

11. Donnez J, Silber S, Andersen CY, Demeestere I, Piver P, Meirow D, Pellicer A, Dolmans MM: Children born after autotransplantation of cryopreserved ovarian tissue. A review of 13 live births. Ann Med 2011, 43:437-450.

12. Fabbri R, Pasquinelli G, Keane D, Mozzanega B, Magnani V, Tamburini F, Venturoli S: Culture of cryopreserved ovarian tissue: state of the art in 2008. Fertil Steril 2009, 91:1619-1629.

13. Smitz J, Dolmans MM, Donnez J, Fortune JE, Hovatta O, Jewgenow K, Picton HM, Plancha C, Shea LD, Stouffer RL, Telfer EE, Woodruff TK, Zelinski MB: Current achievements and future research directions in ovarian tissue culture, in vitro follicle development and transplantation: implications for fertility preservation. Hum Reprod Update 2010, 16:395-414.

14. Gosden RG: Gonadal tissue cryopreservation and transplantation. Reprod Biomed Online 2002, 4(S1):64-67.

15. Jurema MW, Nogueira D: In vitro maturation of human oocytes or assisted reproduction. Fertil Steril 2006, 86:1277-1291.

16. Edwards RG: IVF, IVM, natural cycle IVF, minimal stimulation IVF-time for a rethink. Reprod Biomed Online 2007, 15:106-119.

17. Oktay K, Cil AP, Bang H: Efficiency of oocyte cryopreservation: a metaanalysis. Fertil Steril 2006, 86:70-80.

18. Kuwayama M, Vajta G, Kato O, Leibo SP: Highly efficient vitrification method for cryopreservation of human oocytes. Reprod Biomed Online 2005, 11:300-308.

19. Chian RC, Huang JY, Tan SL, Lucena E, Saa A, Rojas A, Ruvalcaba Castellón LA, García Amador MI, Montoya Sarmiento JE: Obstetric and perinatal outcome in 200 infants conceived from vitrified oocytes. Reprod Biomed Online 2008, 16:608-610.

20. Cobo A, Vajta G, Remohí J: Vitrification of human mature oocytes in clinical practice. Reprod Biomed Online 2009, 19:4385.

21. Nagy ZP, Chang CC, Shapiro DB, Bernal DP, Kort HI, Vajta G: The efficacy and safety of human oocyte vitrification. Semin Reprod Med 2009, 27:450-455.

22. Tao T, Zhang W, Del Valle A: Human oocyte cryopreservation. Curr Opin Obstet Gynecol 2009, 21:247-252.

23. Dolmans MM, Demylle D, Martinez-Madrid B, Donnez J: Efficacy of in vitro fertilization after chemotherapy. Fertil Steril 2005, 83:897-901.
24. Demeestere I, Simon P, Emiliani S, Delbaere A, Englert Y: Orthotopic and heterotopic ovarian tissue transplantation. Hum Reprod Update 2009, 15:649-665.

25. Dolmans MM, Marinescu C, Saussoy P, Van Langendonckt A, Amorim C, Donnez J: Reimplantation of cryopreserved ovarian tissue from patients with acute lymphoblastic leukemia is potentially unsafe. Blood 2010, 116:2908-2914.

26. Huang JY, Chian RC, Gilbert L, Fleiszer D, Holzer H, Dermitas E, Elizur SE, Gidoni $Y$, Levin D, Son WY, Tan SL: Retrieval of immature oocytes from unstimulated ovaries followed by in vitro maturation and vitrification: $A$ novel strategy of fertility preservation for breast cancer patients. Am J Surg 2010, 200:177-183.

27. Filali M, Hesters L, Fanchin R, Tachdjian G, Frydman R, Frydman N: Retrospective comparison of two media for in vitro maturation of oocytes. Reprod Biomed Online 2008, 16:250-256

28. Gilchrist RB, Thompson JG: Oocyte maturation: emerging concepts and technologies to improve developmental potential in vitro. Theriogenology 2007, 67:6-15.

29. Mikkelsen A: Strategies in human in-vitro maturation and their clinical outcome. Reprod Biomed Online 2005, 10:593-599.

30. Revel A, Koler M, Simon A, Lewin A, Laufer N, Safran A: Oocyte collection during cryopreservation of the ovarian cortex. Fertil Steril 2003, 79:1237-1279.

31. Azem F, Hasson J, Cohen T, Shwartz T, Mey-Raz N, Almog B, Amit A, BenYosef D: Retrieval of immature oocytes after chemotherapy for Hodgkin's disease and prolonged ovarian down-regulation with gonadotropin-releasing hormone agonist. Fertil Steril 2009, 92:828, e1-2.

32. Huang JY, Buckett WM, Gilbert L, Tan SL, Chian RC: Retrieval of immature oocytes followed by in vitro maturation and vitrification: A case report on a new strategy of fertility preservation in women with borderline ovarian malignancy. Gynecol Oncol 2007, 105:542-544

33. Isachenko E, Rahimi G, Isachenko V, Narworth F: In-vitro maturation of germinal vesicle oocytes and cryopreservation in metaphase I/II: a possible additional option to preserve fertility during ovarian tissue cryopreservation. Reprod Biomed Online 2004, 8:553-557.

34. Revel A, Revel-Vilk S, Aizenman E, Porat-Katz A, Safran A, Ben-meir A Weintraub M, Shapira M, Achache $H$, Laufer N: At what age can human oocytes be obtained? Fertil Steril 2009, 92:458-463.

35. Chian RC, Buckett WM, Abdul Jalil AK, Son WY, Sylvestre C, Rao D, Tan SL: Natural cycle in-vitro fertilization combined with in-vitro maturation of immature oocytes is an alternative approach in infertility treatment. Fertil Steril 2004, 82:1675-1678.

36. Jurema MW, Nogueira D: In vitro maturation of human oocytes for assisted re production. Fertil Steril 2006, 86:1277-1291.

37. Soderstrom-Anttila V, Makinen S, Turi T, Suikkari AM: Favorable pregnancy results with insemination of in vitro matured oocytes from unstimulated patients. Hum Reprod 2005, 20:1534-1540.

38. Gardner DK, Sheehan CB, Rienzi L, Katz-Jaffe M, Larman MG: Analysis of oocyte physiology to improve cryopreservation procedure. Theriogenology 2007, 67:64-72.

39. Larman MG, Minasi MG, Rienzi L, Gardner DK: Maintenance of the meiotic spindle during vitrification in human and mouse oocyte. Reprod Biomed Online 2007, 15:692-700.

40. Oktay K, Cil AP, Bang H: Efficiency of oocyte cryopreservation: a metaanalysis. Fertil Steril 2006, 86:70-80.

41. Chian RC, Huang JY, Tan SL, Lucena E, Saa A, Rojas A, Ruvacaba Castellon LA, Garcia Amador MI, Montoya Sarmiento JE: Obstetric and perinatal outcome in 200 infants conceived from vitrified oocytes. Reprod Biomed Online 2008, 16:608-610.

42. Chian RC, Huang JY, Gilbert L, Son WY, Holzer H, Cui SJ, Buckett WM, Tulandi T, Tan SL: Obstetric outcomes following vitrification of in vitro and in vivo matured oocytes. Fertil Steril 2009, 91:2391-2398.

43. Cobo A, Kuwayama M, Pérez S, Ruiz A, Pellicer A, Remohi J: Comparison of concomitant outcome achieved with fresh and cryopreserved donor oocytes by the cryotop method. Fertil Steril 2008, 89:657-664.

doi:10.1186/1477-7827-9-150

Cite this article as: Fasano et al:: Vitrification of in vitro matured oocytes collected from antral follicles at the time of ovarian tissue cryopreservation. Reproductive Biology and Endocrinology 2011 9:150. 